\title{
Revised recommendations from the CSO- HNS taskforce on performance of tracheotomy during the COVID-19 pandemic - what a difference a year makes
}

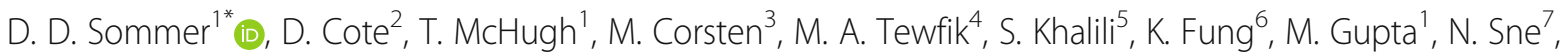 \\ P. T. Engels ${ }^{7}$, E. Weitzel ${ }^{8}$, T. F. E. Brown ${ }^{3}$, J. Paul ${ }^{9}$, K. M. Kost ${ }^{4}$, J. A. Anderson ${ }^{10}$, L. Sowerby ${ }^{6}$, D. Mertz ${ }^{11}$ and \\ I. J. Witterick ${ }^{10}$
}

\begin{abstract}
Background: During the early part of the COVID-19 pandemic, the Canadian Society of Otolaryngology - Head \& Neck Surgery (CSO-HNS) task force published recommendations on performance of tracheotomy. Since then, our understanding of the virus has evolved with ongoing intensive research efforts. New literature has helped us better understand various aspects including patient outcomes and health care worker (HCW) risks associated with tracheotomy during the COVID-19 pandemic. Accordingly, the task force has re-evaluated and revised some of the previous recommendations.

Main body: Based on recent evidence, a negative reverse transcription polymerase chain reaction (RT-PCR) COVID19 swab status is no longer the main deciding factor in the timing of tracheotomy. Instead, tracheotomy may be considered as soon as COVID-19 swab positive patients are greater than 20 days beyond initial symptoms and 2 weeks of mechanical ventilation. Furthermore, both open and percutaneous surgical techniques may be considered with both techniques showing similar safety and outcome profiles. Additional recommendations with discussion of current evidence are presented.

Conclusion: These revised recommendations apply new evidence in optimizing patient and health care system outcomes as well as minimizing risks of COVID-19 transmission during aerosol-generating tracheotomy procedures. As previously noted, additional evidence may lead to further evolution of these and other similar recommendations.
\end{abstract}

Keywords: Tracheotomy, Tracheostomy, COVID-19, SARS-CoV-2, Coronavirus, Intensive Care Unit/ICU, Critical Care, Mechanical Ventilation, Ventilator Weaning, Aerosol Generating Medical Procedure/AGMP, Percutaneous

\footnotetext{
* Correspondence: cso.hns@sympatico.ca

'Division of Otolaryngology - Head \& Neck Surgery - Department of Surgery, McMaster University, Hamilton, ON, Canada

Full list of author information is available at the end of the article
}

(C) The Author(s). 2021 Open Access This article is licensed under a Creative Commons Attribution 4.0 International License, which permits use, sharing, adaptation, distribution and reproduction in any medium or format, as long as you give appropriate credit to the original author(s) and the source, provide a link to the Creative Commons licence, and indicate if changes were made. The images or other third party material in this article are included in the article's Creative Commons licence, unless indicated otherwise in a credit line to the material. If material is not included in the article's Creative Commons licence and your intended use is not permitted by statutory regulation or exceeds the permitted use, you will need to obtain permission directly from the copyright holder. To view a copy of this licence, visit http://creativecommons.org/licenses/by/4.0/ The Creative Commons Public Domain Dedication waiver (http://creativecommons.org/publicdomain/zero/1.0/) applies to the data made available in this article, unless otherwise stated in a credit line to the data. 


\section{Introduction}

In April 2020, the CSO-HNS (Canadian Society of Otolaryngology-Head \& Neck Surgery) taskforce published recommendations on performance of tracheotomy during the COVID-19 pandemic [1]. Tracheotomy is considered an AGMP (aerosol generating medical procedure) with significant risks of viral transmission [2-4]. Since then, there has been a growing body of evidence that has helped guide management decisions, however, some issues such as mutant viral strains continue to evolve while others remain unclear.

\section{Utility of performing tracheotomy in the critical care COVID-19 population}

Recent systematic reviews have attempted to assess the utility of performing tracheotomy in the critically ill COVID-19 patient population [2, 4]. While these suggest some potential benefits in terms of decreased ICU (intensive care unit) stay and overall mortality, the level of heterogeneity and possible selection bias leave interpretation of these results open. There is likely a significant subgroup of patients with respiratory failure to wean and few other comorbidities that would potentially benefit from this intervention. Similarly, risks of tracheal/laryngeal injury with prolonged intubation of greater than 2-3 weeks need to be considered [5]. To date, there is insufficient evidence to suggest COVID 19 patients are substantially different in their risk for glottic injury than other ARDS (acute respiratory distress syndrome) prolonged intubated patients. Given the often delayed timing of tracheotomy in COVID 19 patients, it is possible that there is increased risk of laryngeal complications as a long-term sequelae [6].

\section{Changes to previous recommendations Defining COVID-19 positive status}

The most significant changes in these recommendations pertain to reliance on a negative RT-PCR (reverse transcription polymerase chain reaction) test prior to proceeding with tracheotomy. In the earlier version of the recommendations, the consensus specified awaiting conversion to negative RT-PCR COVID-19 status. Since that time, several studies have described viral load dynamics as evidenced by a comparison of duration of viral shedding assessed by RT-PCR (viral fragments) vs detection of viable virus from time of symptom onset [7]. This evaluation of pooled data indicates that RTPCR may remain positive for a mean of 17 days after onset of symptoms and has even been reported up to 83 days. Recent viral culture studies [8] have confirmed that viable virus has not been recovered in mild to moderate cases after 10 days, and in severe cases after 20 days with the risk of viral shedding dropping below $5 \%$ after 15.2 days [9]. Only rarely, in severely immunocompromised individuals, viable virus has been detected after 20 or more days $[8,10]$.

- We thus recommend a time-based evaluation of disease progression to define COVID-19 positivity and help guide decision making regarding performance of tracheotomy.

- Based on the recent CDC (Centers for Disease Control and Prevention) guidelines [8], a COVID-19 positive patient with severe to critical illness has been defined as cleared of the COVID-19 virus if it has been more than 20 days since (the earlier of) symptom onset or first positive diagnostic test. Prolonged RT-PCR can continue to be positive for up to 3 months after illness onset and does not necessarily denote transmissible disease and may represent inactive viral particles [9].

\section{COVID-19 RT-PCR positive ( $<20$ days)}

- If a patient is COVID-19 positive and it has been less than 20 days since symptom onset or first positive RT-PCR, we recommend against performing a tracheotomy in this group of patients who are potentially still infectious $[2,3,11,12]$. This should only generally be considered in this situation if the endotracheal tube is proving insufficient to provide an adequate airway, or an emergent procedure is required [1]. Enhanced PPE and environmental precautions are advised in these situations.

- In these patients, requests for tracheotomy should be considered in exceptional circumstances on a case-by-case basis with thorough discussion of the risks and benefits between the ICU staff and the attending surgeon.

\section{COVID-19 RT-PCR positive (> 20 days)}

- If a patient is COVID-19 positive and it has been more than 20 days since symptom onset or first positive diagnostic test, a tracheotomy can be performed if otherwise clinically indicated.

- In general, patients undergoing consideration for tracheotomy should be mechanically ventilated/ intubated for over 14 days.

- These patients may be considered "COVID-19 negative" for the purposes of tracheotomy, and the recommendations below should be followed. Postoperatively, these patients may be cared for as per local institution/regional protocols which may depend on COVID-19 RT-PCR testing with associated PPE and precautions. 
Table 1 Summary of changes comparing previous and current taskforce recommendations

\begin{tabular}{lll}
\hline & Previous taskforce recommendation & Current (revised) taskforce recommendation \\
\hline $\begin{array}{l}\text { Covid } \\
\text { transmission } \\
\text { risk }\end{array}$ & $\begin{array}{l}\text { Suspected to be low only after the patient tested } \\
\text { negative with RT-PCR (regardless of time/duration of } \\
\text { symptoms) }\end{array}$ & $\begin{array}{l}\text { Evidence suggests being low if }>20 \text { days from initial symptom onset/ } \\
\text { initial positive COVID RT-PCR test and }>2 \text { weeks of mechanical } \\
\text { ventilation. }\end{array}$ \\
$\begin{array}{l}\text { Vaccination } \\
\text { status }\end{array}$ & N/A & If available, vaccination of surgical/anesthetic/HCW team involved. \\
$\begin{array}{l}\text { Surgical } \\
\text { technique }\end{array}$ & Preference for open tracheotomy & $\begin{array}{l}\text { Open or percutaneous tracheotomy appear to have similar outcomes } \\
\text { and risks to the patient and HCWs involved. }\end{array}$ \\
\hline
\end{tabular}

$R T-P C R$ reverse transcription polymerase chain reaction, $H C W$ healthcare workers

\section{COVID-19 RT-PCR negative}

- We are recommending (at minimum) N95 masks and full face/eye protection to be worn by the surgical team due to the possibility of false negative COVID-19 testing [13]. A negative result does not exclude the possibility of COVID-19 [14]. However, local epidemiology should be considered, and in time periods of low local epidemiology, the risk of a random patient to be unknowingly COVID-19 positive becomes negligible.

- Additionally, any other upper airway surgery that must proceed should have the requirement of COVID-19 testing/clearance of the patient before initiating surgery.

\section{COVID-19 unknown status}

- For emergent tracheotomy with unknown COVID19 status, our recommendations remain generally unchanged from previous. This includes the use of full aerosol PPE including N95 masks with full face/ eye protection. Powered air purifying respirator (PAPR)/N99* equipment or equivalent is an option if available.

$\bigcirc$ *Although there is limited evidence to suggest possible superiority of PAPRs in limiting HCW exposures with other respiratory viruses (ie. influenza virus) as compared to N95 masks [15], there is currently a lack of field observational studies to suggest a difference in transmission risks to HCWs between the two types of PPE when performing AGMPs in patients with SARS-CoV-2 [16].

- Negative pressure rooms may be preferable if available.

- Intubation rather than tracheotomy is highly preferable if achievable.

- Caution is urged with the use of high flow oxygen/ high flow nasal cannula, as well as unsealed noninvasive ventilation/bilevel positive airway pressure (BIPAP) as these are considered potential AGMPs and risk further transmission of disease [14].

- Intubation and/or tracheotomy should be performed by the most skilled person present to maximize initial attempt success [17], and minimize aerosolization risks.

- Awake tracheotomy and cricothyroidotomy are to be considered high risk for viral plume spread and should be avoided if possible. Only in extenuating circumstances should this be considered. A discussion between team members (e.g., anesthesia, otolaryngology, general/thoracic surgery, trauma team leader, emergency physician, critical care physician) should be undertaken to determine the risk/benefit profile for each situation.

\section{COVID-19 positive (> 90 days)}

- If a patient is COVID-19 positive and it has been more than 3-6 months since initial positive result,

Table 2 Summary of recommendations based on RT-PCR COVID-19 positivity

\begin{tabular}{ll}
\hline Covid-19 RT-PCR & Current Recommendation \\
\hline Positive (<20 DAYS) & $\begin{array}{l}\text { Recommend against performing a tracheotomy in this group of patients who are potentially still infectious, unless urgent } \\
\text { e.g. due to inadequate airway. }\end{array}$ \\
Positive (> 20 DAYS) & $\begin{array}{l}\text { Tracheotomy can be performed if clinically indicated with full aerosol PPE (at least N95 and full face/eye protection for the } \\
\text { surgical team). }\end{array}$ \\
Positive (> 90 DAYS) & $\begin{array}{l}\text { Patients should be retested for COVID-19 and if positive, the patient should be considered potentially infectious (for 20 } \\
\text { days). If the patient is retested for COVID-19 and if negative, should be treated as COVID-19 negative. }\end{array}$ \\
Negative & $\begin{array}{l}\text { Tracheotomy can be performed if clinically indicated with full PPE (N95 and full face/eye protection for the surgical team). } \\
\text { Unknown status }\end{array}$ \\
emergent & $\begin{array}{l}\text { Recommend use of full aerosol PPE including (at least N95 masks with full face/eye protection). Option to use PAPR/N99 } \\
\text { equent or equivalent if available. }\end{array}$
\end{tabular}

$P P E$ personal protective equipment, $P A P R$ powered air purifying respirator 
there is the possibility of reinfection $[8,18,19]$. This may become an increasing issue with the emergence of new variants of SARS-CoV-2.

- In this situation, the patient should be retested for COVID-19 and if positive, the patient should be considered potentially re-infected, and if so, considered positive for $<20$ days.

- If the patient is retested for COVID-19 and if negative, should be treated as COVID-19 negative.

\section{Health care team}

- The recommendation to limit the number of team members during tracheotomy to reduce potential spread of disease remains. Furthermore, the surgical/anesthesia team providing care to the tracheotomy patient is to be fully vaccinated if possible.

- A review of evidence surrounding HCW transmission revealed a relatively low-rate risk of viral transmission overall

\section{Surgical technique}

- Regarding type of tracheotomy, either a percutaneous or open tracheotomy may be performed if clinically indicated. Based on recent evidence [2], outcomes and risk to the patient and healthcare workers appear to be similar for performance of both percutaneous tracheotomy and open tracheotomy [20, 21].

\section{Caveats}

As previously noted, the COVID-19 pandemic has been fraught with a continuously changing situation. While the improved availability of PPE, treatments and both patient and $\mathrm{HCW}$ vaccine status may herald a possible light at the end of the tunnel, opposing factors such as more contagious/virulent viral variants and vaccine fears threaten this progress. Such aspects as well as further evidence may lead to further evolution of these and other similar recommendations. Although patient vaccination status and similar aforementioned factors likely affect disease course and health care worker transmission risk in these cases, data is still too limited at this time and further analysis is warranted.

\section{Summary of changes}

The taskforce recommends that it is reasonable to consider tracheotomy after (the greater of) 2 weeks duration of mechanical ventilation or greater than 20 days after symptoms emerge/first positive RT-PCR test. However, we recommend this decision is made on a case-by-case basis based on the overall trajectory of the patient's outcome and comorbidities whereby performance of a tracheotomy will be more likely to provide a benefit to the patient's outcome. This should be weighed alongside ICU capacity, resources and surgical considerations. Open surgical and percutaneous techniques appear to have similar safety and outcome profiles. These recommendations are not meant to supersede local governmental or institutional guidelines. See Table 1 for a summary of the main changes comparing the previous and current version. See Table 2 for a summary of the current recommendations based on COVID RT-PCR positivity.

\section{Abbreviations \\ AGMP: Aerosol generating medical procedure; ARDS: Acute respiratory distress syndrome; CDC: Centers for Disease Control and Prevention; CSO- HNS: Canadian Society of Otolaryngology-Head \& Neck Surgery; HCW: Health care worker; ICU: Intensive care unit; PPE: Personal protective equipment; PAPR: Powered air purifying respirator; RT-PCR: Reverse transcription polymerase chain reaction}

\section{Acknowledgements \\ Not applicable.}

\begin{abstract}
Disclaimer
The Canadian Society of Otolaryngology - Head \& Neck Surgery (CSO-HNS) has developed this information as guidance for its members. This is based on information available at the time of writing (March 30, 2020) and the Society recognizes that the situation is evolving rapidly, so recommendations may change. The guidance included in this document does not replace regular standards of care, nor do they replace the application of clinical judgement to each individual presentation, nor variations due to jurisdiction or facility type.

The views expressed in this presentation are those of the author(s) and do not reflect the official policy or position of the U.S. Army, Department of Defense, or the U.S. Government.

The CSO-HNS is not liable for the accuracy or completeness of the information in this document. The information in this document cannot replace professional advice.
\end{abstract}

\section{Authors' contributions}

DDS and PTE devised the project. IJW and DDS organized and coordinated group consensus discussions. All authors contributed substantially to the manuscript and reviewed and approved the final version.

\section{Funding}

None.

\section{Declarations}

Ethics approval and consent to participate Not applicable.

\section{Consent for publication}

Not applicable.

\section{Competing interests}

The authors declare that they have no competing interests.

\section{Author details}

${ }^{1}$ Division of Otolaryngology - Head \& Neck Surgery - Department of Surgery, McMaster University, Hamilton, ON, Canada. ${ }^{2}$ Division of Otolaryngology Head and Neck Surgery, University of Alberta, Edmonton, AB, Canada. ${ }^{3}$ Division of Otolaryngology - Head \& Neck Surgery, Dalhousie University, Halifax, NS, Canada. ${ }^{4}$ Department of Otolaryngology - Head and Neck Surgery, McGill University, Montreal, QC, Canada. ${ }^{5}$ Aurora Neuroscience Innovation Institute, Milwaukee, WI, USA. ${ }^{6}$ Department of Otolaryngology Head and Neck Surgery, Western University, London, ON, Canada. 
${ }^{7}$ Department of Surgery and Critical Care, McMaster University, Hamilton, ON, Canada. ${ }^{8}$ Department of Otolaryngology Head and Neck Surgery, Lackland Air Force Base, Wilford Hall Medical Center, San Antonio, TX, USA. ${ }^{9}$ Department of Anesthesia, McMaster University, Hamilton, ON, Canada. ${ }^{10}$ Department of Otolaryngology - Head \& Neck Surgery, University of Toronto, Toronto, ON, Canada. ${ }^{11}$ Division of Infectious Disease, Department of Medicine, McMaster University, Hamilton, ON, Canada.

Received: 20 May 2021 Accepted: 5 July 2021

Published online: 20 October 2021

\section{References}

1. Sommer DD, Engels PT, Weitzel EK, Khalili S, Corsten M, Tewfik MA, et al. Recommendations from the CSO-HNS taskforce on performance of tracheotomy during the COVID-19 pandemic. J Otolaryngol Head Neck Surg. 2020;49(1):23. https://doi.org/10.1186/s40463-020-00414-9.

2. Staibano P, Levin M, McHugh T, Gupta M, Sommer DD. Association of Tracheostomy with Outcomes in patients with COVID-19 and SARS-CoV-2 transmission among health care professionals: a systematic review and meta-analysis. JAMA Otolaryngol Head Neck Surg. 2021;147(7):646-55. https://doi.org/10.1001/jamaoto.2021.0930.

3. Sowerby LJ, Stephenson K, Dickie A, Lella FAD, Jefferson N, North $H$, et al. International registry of otolaryngologist-head and neck surgeons with COVID-19. Int Forum Allergy Rhinol. 2020;10(11):1201-8. https://doi.org/10.1 002/alr.22677.

4. Benito DA, Bestourous DE, Tong JY, et al. Tracheotomy in COVID-19 patients: a systematic review and meta-analysis of weaning, Decannulation, and survival. Otolaryngol Head Neck Surg. 2021:194599820984780.

5. Fiacchini G, Tricò D, Ribechini A, Forfori F, Brogi E, Lucchi M, et al. Evaluation of the incidence and potential mechanisms of tracheal complications in patients with COVID-19. JAMA Otolaryngol Head Neck Surg. 2021;147(1):706. https://doi.org/10.1001/jamaoto.2020.4148.

6. Rouhani MJ, Clunie G, Thong G, Lovell L, Roe J, Ashcroft M, et al. A prospective study of voice, swallow, and airway outcomes following tracheostomy for COVID-19. Laryngoscope. 2021;131(6):E1918-E25. https:// doi.org/10.1002/lary.29346.

7. He X, Lau EHY, Wu P, Deng X, Wang J, Hao X, et al. Temporal dynamics in viral shedding and transmissibility of COVID-19. Nat Med. 2020;26(5):672-5. https://doi.org/10.1038/s41591-020-0869-5

8. CDC. Duration of isolation and precautions for adults with COVID-19: Centers for disease control and prevention: CDC; 2020. Available from: https://www.cdc.gov/coronavirus/2019-ncov/hcp/duration-isolation.html. Accessed 1 June 2021

9. van Kampen JJA, van de Vijver DAMC, Fraaij PLA, Haagmans BL, Lamers MM Okba N, et al. Duration and key determinants of infectious virus shedding in hospitalized patients with coronavirus disease-2019 (COVID-19). Nat Commun. 2021;12(1):267. https://doi.org/10.1038/s41467-020-20568-4.

10. Aydillo T, Gonzalez-Reiche AS, Aslam S, van de Guchte A, Khan Z, Obla A, et al. Shedding of viable SARS-CoV-2 after immunosuppressive therapy for cancer. N Engl J Med. 2020;383(26):2586-8. https://doi.org/10.1056/NEJMc2 031670.

11. Xu K, Zhang XH, Long XB, Lu X, Liu Z. An environmental study of tracheostomy on eight COVID-19 patients. J Otolaryngol Head Neck Surg. 2021;50(1):3. https://doi.org/10.1186/s40463-021-00494-1.

12. Volo T, Stritoni P, Battel I, Zennaro B, Lazzari F, Bellin M, et al. Elective tracheostomy during COVID-19 outbreak: to whom, when, how? Early experience from Venice, Italy. Eur Arch Otorhinolaryngol. 2021;278(3):781-9. https://doi.org/10.1007/s00405-020-06190-6.

13. Li D, Wang D, Dong J, Wang $\mathrm{N}$, Huang $\mathrm{H}, \mathrm{Xu} \mathrm{H}$, et al. False-negative results of real-time reverse-transcriptase polymerase chain reaction for severe acute respiratory syndrome coronavirus 2: role of deep-learning-based CT diagnosis and insights from two cases. Korean J Radiol. 2020;21(4):505-8. https://doi.org/10.3348/kj.2020.0146.

14. Brewster DJ, Groombridge CJ, Gatward JJ. Consensus statement: Safe Airway Society principles of airway management and tracheal intubation specific to the COVID-19 adult patient group. Med J Aust. 2021;214(1):46-e1.

15. Bischoff WE, Turner J, Russell G, et al. How well do N95 respirators protect healthcare providers against aerosolized influenza virus? Infect Control Hosp Epidemiol. 2018:1-3.

16. Licina A, Silvers A. Use of powered air-purifying respirator(PAPR) as part of protective equipment against SARS-CoV-2-a narrative review and critical appraisal of evidence. Am J Infect Control. 2021;49(4):492-9. https://doi. org/10.1016/j.ajic.2020.11.009

17. Cheung JC, Ho LT, Cheng JV, et al. Staff safety during emergency airway management for COVID-19 in Hong Kong. Lancet Respir Med. 2020;8(4):e19. https://doi.org/10.1016/\$2213-2600(20)30084-9.

18. Gudbjartsson DF, Norddahl GL, Melsted P, Gunnarsdottir K, Holm H, Eythorsson E, et al. Humoral immune response to SARS-CoV-2 in Iceland. N Engl J Med. 2020;383(18):1724-34. https://doi.org/10.1056/NEJMoa2026116.

19. Wajnberg $A$, Amanat $F$, Firpo $A$, et al. SARS-CoV-2 infection induces robust, neutralizing antibody responses that are stable for at least three months. medRxiv. 2020:2020.07.14.20151126.

20. Botti C, Lusetti F, Peroni S, et al. The role of tracheotomy and timing of weaning and Decannulation in patients affected by severe COVID-19. Ear Nose Throat J. 2020:145561320965196.

21. Zhang G, Hu C, Luo L, Fang F, Chen Y, Li J, et al. Clinical features and shortterm outcomes of 221 patients with COVID-19 in Wuhan, China. J Clin Virol. 2020;127:104364. https://doi.org/10.1016/j.jcv.2020.104364.

\section{Publisher's Note}

Springer Nature remains neutral with regard to jurisdictional claims in published maps and institutional affiliations.

Ready to submit your research? Choose BMC and benefit from:

- fast, convenient online submission

- thorough peer review by experienced researchers in your field

- rapid publication on acceptance

- support for research data, including large and complex data types

- gold Open Access which fosters wider collaboration and increased citations

- maximum visibility for your research: over $100 \mathrm{M}$ website views per year

At BMC, research is always in progress.

Learn more biomedcentral.com/submissions 